\title{
Assessment of Technology Options Addressing Agricultural Production Constraints in Western Kenya
}

\author{
${ }^{* 1}$ Kelvin Mark Mtei, ${ }^{1}$ Ajebesone Francis Ngome, \\ Stephen Wambua' ${ }^{2}$ and ${ }^{1}$ Mathias Becker
}

\author{
${ }^{1}$ Institute of Crop Science and Resource Conservation (INRES), Department of Plant Nutrition, \\ University of Bonn, Karlrobert Kreiten Straße 13, 53115 Bonn, Germany. \\ ${ }^{2}$ Department of Agricultural Economics and Rural Development, University of Göttingen, Platz \\ der Göttinger Sieben 5, D-37073, Göttingen,Germany.
}

\section{ARTICLE INFO}

Article No.: 102412135

DOI: 10.15580/GJAS.2013.3.102412135

Submitted: $24 / 10 / 2012$

Accepted: 23/03/2013

Published: 29/03/2013

${ }^{\star}$ Corresponding Author

Kelvin Mark Mtei

E-mail: mackytz@yahoo.com

\section{Keywords:}

Alfisol, economic feasibility, organic manure, seed priming, site-specific technology Ultisol

\section{ABSTRACT}

Poor soil fertility and weed infestation are among major constraints facing agricultural production in Western Kenya. Recommended technologies differ in resource requirement and their effectiveness are seasonal site-specific. On-farm experiments were conducted during $2008 / 09$ cropping seasons on two soil types of western Kenya using maize as a test crop. Seven technology options were assessed on agronomic performance, resource requirement, and economic returns. Maize grain yield differed between cropping seasons with generally higher yields during long rainy season, and across soil types with organic manure-based options performing better on Ultisol than on Alfisol. Response of soil parameters reflected the amount of added nutrients and soil type with strongest effect of added $\mathbf{N}$ on Alfisol and of added $\mathbf{P}$ on Ultisol. All options significantly reduced weed biomass in the maize fields in the long $(>90 \%)$ than in the short rainy seasons ( $>50 \%$ ). Green manure-based option required more labour while mineral fertilizer-based options required largest capital. The economic netbenefit varied between -112 and $+892 €$ ha- $^{-1}$ with highest values in organic manure-based options during short rainy season and in mineral fertilizer-based options during long rainy season. This example illustrates the need to define sitespecific technology evaluation for successful targeting of technology options. 


\section{INTRODUCTION}

In much of the sub-Saharan Africa, rural households largely depend on farming (FAO, 2011). Particularly in western Kenya, rapid population growth, continuous cropping with limited use of organic and inorganic inputs on the degraded soils (Okalebo et al., 2006) and coupled with erratic seasonal rains (Asch and Huelsebusch, 2009) have resulted in declining agricultural productivity, poor rural livelihood and poverty rates that are among the highest in Kenya (Giller et al., 2011). The main culprits for the decline in agricultural productivity and frequent food shortages in the predominant low-input systems are the decline in soil fertility and weed infestation. Thus, innovative enhancement of soil fertility and weed control is an important step for improved agricultural productivity and poverty alleviation in Western Kenya (Okalebo et al., 2006).

Smallholder farming systems in the region are highly dynamic (Tittonell et al., 2005a). They are characterized by various interacting socio-economic and biophysical subcomponents (Diwani and Becker, 2009) which drive farmers' decision-making on production objectives and soil fertility management (Tittonell et al., 2005b). These socio-ecological niche environments are defined by resource availability and resource base quality and differ between farm types, prevailing soil types and seasons (Ojiem et al., 2006). Consequently, there is a large heterogeneity in key production constraints associated with resource base quality, the farm level availability of production factors (land, labour, capital, knowhow) and the production orientation (subsistence vs. sale) (Diwani and Becker, 2009). Technology options for tackling these production constraints have been developed and widely tested in this region (FURP, 1994) but adoption rates are generally poor (Waithaka et al., 2006). Technologies differ in terms of their requirement for production factors (Doss, 2006) which strongly differ between farm types (Giller et al., 2006). These production factors involve (i) Labour (i.e. tillage operations, manual weed control and use of organic manures), (ii) Capital (i.e. purchasing inorganic fertilizers), (iii) Land (field areas occupied by improved fallows and cover crops), and (iv) Know-how (knowledge-intensive technologies requiring generally good and regular contacts with extension officers) (Jama et al., 2000).

Smallholder farmers appreciate the benefits that can be reaped from these technology options, yet when they are implemented by farmers, constraints arise often due to lack of or competing uses for land, labour, cash or organic resources (Giller et al., 2011). The frequently applied blanket recommendations do not consider the diverse socio-ecological situations (resource availability and resource base quality) facing farmers at household level (Tittonell et al., 2010) and the site- and system-specific niche environments for technology adoption (Ojiem et al., 2006). The use of mineral fertilizer is limited by cost and accessibility (Woomer et al., 2003) such that the few farmers using mineral fertilizers often do not apply the recommended rates, resulting to poor outputs (Vanlauwe et al., 2006). Organic-based technologies on the other hand, are either labour-(farm yard manure) or land-intensive (green manures) and the effectiveness often depends on season and soil attributes (Becker et al., 1994; Ngome et al., 2011). Thus, technological interventions designed to improve farm productivity need to target the socially diverse and ecologically heterogeneous farms and farming system situations (Ngome et al., 2011) to arrive at farm types- and farming systemsspecific recommendation domains or socio-ecological niches (Ojiem et al., 2006). This requires an initial characterization and grouping (typology) of the farming systems with similar biophysical and socio-economic properties (Tittonell et al., 2005b). Previously, typology studies have been done in western Kenya at different scales and based on different indicators such as wealth (Shepherd and Soule, 1998), the availability of production factors (Tittonell et al., 2005b) or the biophysical environment (Diwani and Becker, 2009). Based on typology indicators, technologies may be targeted with reference to their specific attributes as well as the farm's resource availability and resource base quality. Therefore, there is a need to identify options that are adapted and adoptable within the context of farmer's resource availability and biophysical factors (Odendo et al., 2006).

Crop productivity in this region is seen to largely depend on dominant soil type (Alfisol and Ultisol) and cropping (short and long rainy) seasons and on the farm type mainly differentiated by production orientation (subsistence vs marketoriented) (Diwani and Becker, 2009). This diversity of situations makes western Kenya an interesting case to test technology-targeting in the frame of the socioeconomic and biophysical factors (Ngome et al., 2011; Giller et al., 2011; Ojiem et al., 2006) to attain sustainable agriculture (Wall and Smith, 2005). Based on production factors availability, seasonal effects and soil types, productivity gains from use of soil fertilityimproving technologies are bound to vary. Therefore the objectives of this study were to: (i) assess agronomic performance (yield, weed control, soil fertility effects); (ii) compare requirements in terms of production factor availability (land, labour, capital, know-how) and (iii) evaluate the economic feasibility (net benefits, marginal rate of return) of maize production and soil fertility-improving technology options in different soils, cropping seasons and farm types of western Kenya.

\section{MATERIALS AND METHODS}

\section{Site selection and characteristics}

The study was conducted in Kakamega region, Western Province of Kenya intending to capture the prevailing heterogeneity in soil type, seasonal rainfall amounts and major farm types. The two dominant soil types are Alfisol and Ultisol (Jaetzold et al., 2005) and vary in chemical properties (Table 1). The mean annual rainfall ranges from 1600 to $2200 \mathrm{~mm}$ with a 
distinct bimodal pattern (Fig. 1). The dominant farm types differ in farm size and production orientation and have been classified into six cluster groups with four located on Alfisols and two on Ultisols (Diwani and Becker, 2009). Experimental sites were therefore located on either Alfisols that dominate the northern part (Lubao division) or on Ultisols that dominate the eastern part (Shinyalu division) and experience about
$30 \%$ higher average annual rainfall than the Alfisol area. Four farmer's fields were selected (two on each soil type). Maize was chosen as the reference crop because of its role as the main staple food and the first priority crop for receiving inputs or for farmers to target soil-improving technologies. Detailed characteristics of the study sites are summarized in Table 1 .

Table 1: Climatic conditions and soil characteristics of two major maize-growing environments in western Kenya

\begin{tabular}{|l|l|l|}
\hline \multirow{2}{*}{ Parameter } & \multicolumn{2}{|c|}{ Soil type } \\
\cline { 2 - 3 } & Alfisol & Ultisol \\
\hline Altitude $(\mathrm{masl})$ & 1558 & 1569 \\
\hline Latitude & $\mathrm{N} 00^{\circ} 19.180^{\prime}$ & ${\mathrm{N} 00^{\circ} 14.548^{\prime}}^{\prime}$ \\
\hline Longitude & $\mathrm{E} 034^{\circ} 47.793^{\prime}$ & $\mathrm{E} 034^{\circ} 51.129^{\prime}$ \\
\hline Total annual rainfall $(\mathrm{mm})^{\underline{a}}$ & $1200-1600$ & $2000-2300$ \\
\hline Mean temperature $\left({ }^{\circ} \mathrm{C}\right)^{\underline{a}}$ & $18-21$ & $18-21$ \\
\hline Sand $(\%)$ & 61.2 & 10.8 \\
\hline Silt $(\%)$ & 20.0 & 27.0 \\
\hline Clay $(\%)$ & 18.8 & 62.2 \\
\hline pH $\left(\mathrm{H}_{2} 0\right)$ & 5.4 & 4.9 \\
\hline Organic C $(\%)$ & 0.8 & 2.5 \\
\hline Total N $(\%)$ & 0.12 & 0.24 \\
\hline Available P $\left(\mathrm{mg} \mathrm{kg}^{-1}\right)$ & 7.8 & 2.9 \\
\hline
\end{tabular}

a range of annual means 1990-2008

Soil analysis method: Okalebo et al. (2002).

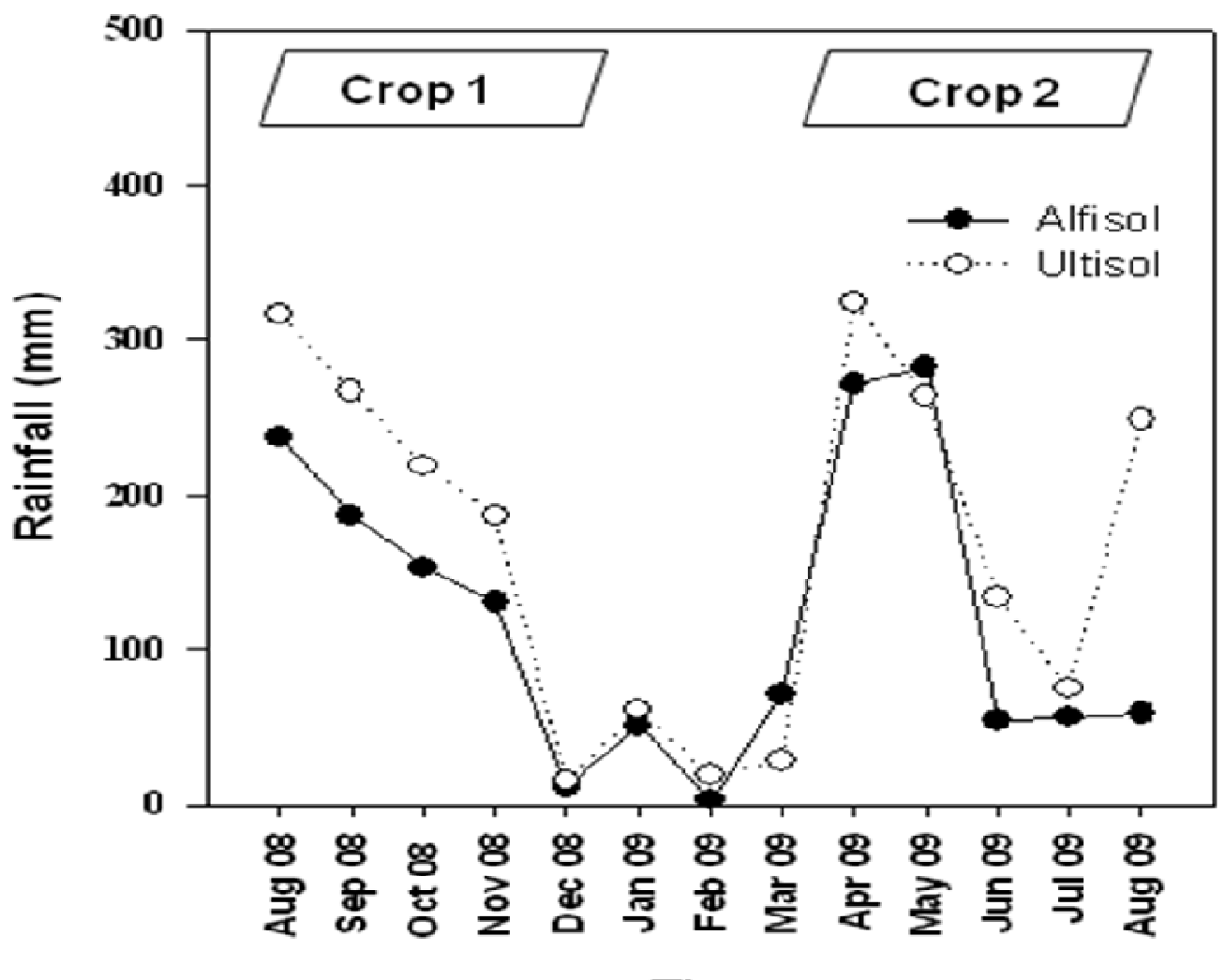

Time

Fig.1: Rainfall distribution during the short and the long rainy seasons of $2008 / 2009$ and the associated maize-cropping periods in western Kenya. 
Treatment selection, application and experimental design

The field experiment was conducted during the short rainy season (August-November) of 2008 and in the long rainy season (February-July) of 2009 (Fig.1). We evaluated the agronomic performance (maize grain yield, weed control, soil quality), production factor requirements (labour, capital, land, knowhow) and economic performance attributes (cost-benefit, marginal analysis) of selected soil fertility-improving technologies. Treatments were selected based on technology options commonly recommended to improve crop yield and soil fertility in the region (FURP, 1994). These comprised: (i) clean weeding; (ii) seed priming; (iii) animal manure; (iv) green manure (Mucuna pruriens var. utilis); (v) zero-tillage with cover crop (Arachis pintoi accession CIAT 18744) and NPfertilizer; (vi) zero-tillage with NP-fertilizer; (vii) NPfertilizer and; (viii) farmer's practice (control).

The experimental layout in the four farms was a randomized complete block design with four replicates and each experimental plot measuring $6 \mathrm{mx}$ $5 \mathrm{~m}$. In the seed priming treatment, maize seeds were soaked in $2 \%$ P-solution (50 $\mathrm{g} \mathrm{P} \mathrm{kg}^{-1}$ maize seeds) to stimulate early seeding vigour (Harris et al., 2001) and to provide initial $\mathrm{P}$ required for early plant growth (Ajouri et al., 2004). Primed seeds were sun-dried to $13-14 \%$ moisture before planting. The cover crop ( $A$. pintol) and green manure crop ( $M$. pruriens) were seeded at $20 \mathrm{~cm} \times 20 \mathrm{~cm}$ and $20 \mathrm{~cm} \times 30$ spacing, respectively with 1 seed per hole at the onset of the short rainy season in August, 2008. While A. pintoi was maintained throughout the two seasons, $M$. pruriens was seeded for the second season at the onset of the long rainy season in March, 2009. Two weeks after seeding the legumes, maize (cultivar HB 520 ) was planted at a spacing of $60 \mathrm{~cm} \times 25 \mathrm{~cm}$ with 2 seeds per hole and thinned to one plant per hole two weeks after emergence. At 6 weeks after seeding (WAS), M. pruriens was uprooted and incorporated between maize rows by using a hand hoe. Mineral nitrogen (100 kg N ha-1) was applied to maize as urea with splits of $40 \%$ basally, $30 \%$ at four and $30 \%$ at six weeks after maize seeding. Mineral phosphorus as triple super phosphate (TSP) was applied as one basal dose at $100 \mathrm{~kg} \mathrm{P}^{-1}$ and $30 \mathrm{~kg} \mathrm{P}^{-1}$ to maize and $M$. puriens, respectively. Weeding and other treatment applications are detailed in Table 2.

Table 2: Technology options with their treatment application to improve maize production and soil fertility of smallholder farms in western Kenya.

\begin{tabular}{|c|c|c|c|}
\hline Options & Inputs to maize crop & Land Tillage & Weeding ${ }^{\mathrm{a}}$ (WAS) \\
\hline Farmer practice (control) & - & Tilled & 2 , by hoe \\
\hline Clean weeding & - & Tilled & 2,4 and 6 , by hoe \\
\hline Seed priming & $2 \% \mathrm{P}\left(\mathrm{CaHPO}_{4}\right)$ & Tilled & 2,4 and 6 , by hoe \\
\hline Animal manure & $\begin{array}{l}\text { Farm yard manure } \\
5000 \mathrm{~kg} \mathrm{ha}^{-1}\end{array}$ & Tilled & 2,4 and 6 , by hoe \\
\hline Green manure $\underline{\underline{b}}$ & $\begin{array}{l}1200 \mathrm{~kg} \text { green biomass } \\
\mathrm{ha}^{-1} \text {, and } 30 \mathrm{~kg} \mathrm{P} \mathrm{ha}^{-1}\end{array}$ & Tilled & 2 and 6 , by hand \\
\hline Cover cropc & $\begin{array}{l}\text { Urea100 kg N ha-1 } \\
\text { TSP } 100 \mathrm{~kg} \mathrm{P} \mathrm{ha}^{-1}\end{array}$ & Not-tilled & 2 , by hand \\
\hline Zero-tillage & $\begin{array}{l}\text { Urea100 kg N ha-1 } \\
\text { TSP } 100 \mathrm{~kg} \mathrm{P} \mathrm{ha}^{-1}\end{array}$ & Not-tilled & 2,4 and 6 , by hand \\
\hline NP-fertilizer & $\begin{array}{l}\text { Urea100 kg N ha-1 } \\
\text { TSP } 100 \mathrm{~kg} \mathrm{P} \mathrm{ha}^{-1}\end{array}$ & Tilled & 2,4 and 6 , by hoe \\
\hline
\end{tabular}

a Weeks after seeding

b Velvet bean (Mucuna pruriens var. utilis)

$\subseteq$ Arachis pintoi (accession CIAT 18744)

Sampling and data collection

Maize plants were harvested at maturity (16 WAS) in a $4 \mathrm{~m}^{2}$ area at the middle rows of each treatment plot. Cobs were removed and shelled. The grain weight and fresh cob weight were recorded in the field, while a sample of 10 cobs was dried and re-weighed. Grain yield was expressed at $13 \%$ moisture content and adjusted to $90 \%$ to cater for the yield decrease upon scaling-up as suggested by CIMMYT (1988).

Soil samples $(0-15 \mathrm{~cm})$ were taken at the beginning and the end of the experiment, processed and packed for laboratory analysis at the Department of Plant Nutrition, University of Bonn, Germany. The changes in soil $\mathrm{N}$ and $\mathrm{P}$ content as a result of a treatment effect were determined. Soil total $\mathrm{N}$ was determined by $\mathrm{CN}$-auto analyzer (EA Euro 3000) and soil extractable $P$ was determined by Bray-I method (Okalebo et al., 2002).

A fixed quadrate $(60 \mathrm{~cm} \times 60 \mathrm{~cm})$ was randomly placed on two spots in each plot and weeds in the quadrat were cut at ground level, pooled and weighed 
to obtain fresh weight while a sub-sample of $200 \mathrm{~g}$ was oven-dried at $70^{\circ} \mathrm{C}$ for $48 \mathrm{~h}$ to constant weight.

Capital requirements were determined from the cost of inputs (seeds, manure, fertilizer and priming material) for each treatment and expressed as $€$ ha $^{-1}$. Labour requirements were recorded separately for each plot and each field activity (land preparation, seeding, fertilizer application and manure incorporation, weeding and harvesting). Total labour was summed-up for each season and expressed as days ha $^{-1}$. Land is an important factor for the landintensive options such as green manure and cover crop particularly when competing for crop land. Observations on land requirements were assessed semi-quantitatively through farmers' and key informants' interview in each season and at each study location during crop establishment and during farmers' field days. Structured questionnaires were administered to inquire about farmers' perception on the requirement for land and know-how to implement the different treatment options and the answers $(n=8$ -13 per site) were ranked on scale of $1-3(1=$ low, 2 = medium, 3 = high).

\section{Data analysis and Economic evaluation}

Data on maize grain yield $\left(\mathrm{Mg} \mathrm{ha}^{-1}\right)$, weed biomass (kg ha-1), total soil $\mathrm{N}(\%)$, extractable soil $\mathrm{P}\left(\mathrm{mg} \mathrm{kg}^{-1}\right)$, labour input (days ha-1) and capital input (€ ha-1) were subjected to analysis of variance. Mean separation was done by Tukey test at $5 \%$ probability level using SPSS statistical package (SPSS, 2008).

The economic analysis required data on total variable cost (TVC) of inputs and values of output per sites and seasons. The TVCs were summed from material-input costs and labour wages while output was calculated from maize grain yield multiplied by its market price in Euros. The labour wages and market price of maize were obtained through a market survey undertaken during the study period. Net benefits were estimated by partial budget technique which considered changes only in costs and returns associated with the treatment application. Costs which were identical in all treatments (land rent, maize seeds, planting and first weeding) were not included in the analysis. Since costs and revenues were spread out over a period of 2 years (2008-2009), a sensitivity analysis was essential. All costs and benefits were discounted at an interest rate of $20 \%$ per annum (which was the average cost of capital that prevailed during the study period) as the discount rate to estimate the present value of future cash flows. The net benefit was thus estimated by the equation below as suggested by Odendo et al. (2006);

Net benefit $=\left(\sum_{1}^{2} \frac{\left(P_{t} Y_{t}\right)}{(1+r)}\right)-\left(\sum_{1}^{2} \frac{(T V C)}{(1+r)}\right)$; where: $P_{t}=$ price of maize grain in year $t, Y_{t}=$ maize grain yield in year $t,(1+r)=$ the discount factor $(20 \%), \frac{(\text { TVC) }}{(1+r)}=$ discounted total variable cost, and $\frac{\left(P_{t} Y_{t}\right)}{(1+r)}=$ discounted gross output.

In addition to net benefit analysis, farm management principles suggest further analysis to assess in a more differentiated way the potential returns to each treatment option (CIMMYT, 1988; Odendo et al., 2006). Treatments with positive net benefits (negative net benefit is not economically feasible) were ranked in ascending order of their total variable costs. Treatments with net benefits either equal or less than the base treatment in the ranking were omitted from the analysis because the base

treatment (farmers practice) had higher returns. Dominance in this study was made with reference to the farmers' practice (control) treatment as the base. The marginal rate of return (MRR) analysis followed the dominance analysis and calculated the expected percentage additional net benefits in return to the extra investment (variable cost) as a result of moving from the current practice to the next option. Thus MRR was done only to non-dominated treatments options as:

$\operatorname{MRR}=\left(\frac{\text { change in net benefits in moving from option1 to option } 2}{\text { change in total variable costs incured in moving from option } 1 \text { to option } 2}\right) \times 100$

The higher the MRR, the more beneficial was the change from the previous option to the next in the rank. A MRR of $100 \%$ implies a return of one unit for each unit of expenditure on a given variable input in a particular option (CIMMYT, 1988). Similar to the dominance analysis, MRR was done based on the control treatment aiming at estimating the benefit obtained by changing from the current farmers' practice to the recommended options.

\section{RESULTS}

\section{Agronomic performance of the technology options}

Generally, technologies differentially affected maize grain yield with largest effects from mineral fertilizerbased options. However this yield response differed a) between cropping seasons, with generally larger response during the long than during the short rainy 
season, and b) by soil type with organic-based technology responding more on Ultisol than on Alfisol (Table 3). Irrespective of seasons and soil types, yield levels in all treatments were significantly higher than in the control. In the short rainy season, mineral fertilizerbased options showed the highest yield (2.0-2.5 Mg $\mathrm{ha}^{-1}$ ) which was three-times more than the yield in the control treatment. Organic manure-based options and seed priming had a yield $>70 \%$ higher than the control.
In the long rainy season, the same trend was observed but yields were $25-100 \%$ more than in the short rain season. Only the zero-tillage treatment combined with cover crop on Alfisol showed a $45 \%$ decrease in yield during the long rainy compared to the short rainy season (Table 3). Yields observed in organic manurebased options, seed priming and clean weeding did not significantly differ ( $p>0.05$ ) among each other in both

seasons.

Table 3: Maize yield response to selected yield and soil fertility-improving technology options on the two soil types dominant in western Kenya (2008/09 cropping seasons).

\begin{tabular}{|l|l|l|l|l|l|l|}
\hline \multirow{2}{*}{ Options } & \multicolumn{3}{|l|}{ Short rainy season } & \multicolumn{3}{l|}{ Long rainy season } \\
\cline { 2 - 6 } & Alfisol & Ultisol & \multicolumn{3}{l|}{ Alfisol } & Ultisol \\
\hline & \multicolumn{4}{|c|}{ Grain yielda $\left(\mathrm{Mg} \mathrm{ha}^{-1}\right)$} \\
\hline Farmer practice (control) & $0.78 d$ & $0.88 c$ & & $0.97 d$ & $0.50 c$ \\
\hline Clean weeding & $1.30 c$ & $1.30 b c$ & & $1.80 b c$ & $2.00 b$ \\
\hline Seed priming & $1.47 c$ & $1.50 b$ & & $2.10 b c$ & $2.00 b$ \\
\hline Animal manure & $1.60 b c$ & $1.58 b$ & & $2.60 b$ & $2.50 b$ \\
\hline Green manure $\underline{\underline{b}}$ & $1.40 c$ & $1.40 b c$ & & $1.90 b c$ & $2.35 b$ \\
\hline Cover crop $\underline{\underline{c}}$ & $2.00 a b$ & $2.30 a$ & & $1.50 c d$ & $3.60 a$ \\
\hline Zero-tillage & $2.35 a$ & $2.30 a$ & & $4.20 a$ & $4.22 a$ \\
\hline NP-fertilizer & $2.47 a$ & $2.43 a$ & & $4.90 a$ & $4.50 a$ \\
\hline
\end{tabular}

a Values are means of 4 replicates. Means followed by the same letter in a column are not significantly different by Tukey test $(\mathrm{P}<0.05)$

$\underline{b}$ Velvet bean (Mucuna pruriens var. utilis)

$\subseteq$ Arachis pintoi (accession CIAT 18744)

Soil parameter responses to technology options were largely determined by the soil type. These responses reflected the amount of added nutrients and were largely limited to the mineral fertilizer-based options. Strongest soil response to added $\mathrm{N}$ was observed in Alfisol while strongest soil response to added $\mathrm{P}$ was observed in Ultisol. Generally, both total soil N and extractable $\mathrm{P}$ increments were significantly higher in the mineral fertilizer-based treatments than in the manure-based treatments, while no effects were observed with clean weeding, seed priming and the control treatments (Table 4). The $30 \mathrm{~kg} \mathrm{P}$ applied to $M$. pruriens at planting resulted to a residual increase of about $10 \mathrm{mg} \mathrm{kg}^{-1}$ extractable $\mathrm{P}$ compared to the initial soil $P$ content in both soils.

Table 4: Effect of technologies to improve yield and soil fertility on soil total nitrogen and Brayextractable soil phosphorus on the two dominant soil types in western Kenya (2008/09 cropping seasons)

\begin{tabular}{|l|l|l|c|c|}
\hline \multirow{2}{*}{ Options } & \multicolumn{2}{|c|}{ Alfisol } & \multicolumn{2}{c|}{ Ultisol } \\
\cline { 2 - 5 } & total Na $(\%)$ & $\mathrm{P}\left(\mathrm{mg} \mathrm{kg}^{-1}\right)$ & total $(\mathrm{N} \%)$ & $\mathrm{P}\left(\mathrm{mg} \mathrm{kg}^{-1}\right)$ \\
\hline Initial level & $0.12 a b$ & $7.8 e$ & $0.24 b$ & $2.9 e$ \\
\hline Farmer practice (control) & $0.11 b$ & $3.9 f$ & $0.23 b$ & $1.5 f$ \\
\hline Clean weeding & $0.11 b$ & $3.9 f$ & $0.23 b$ & $1.5 f$ \\
\hline Seed priming & $0.11 b$ & $3.9 f$ & $0.23 b$ & $1.5 f$ \\
\hline Animal Manure & $0.12 \mathrm{a} b$ & $12.3 d$ & $0.25 b$ & $6.6 d$ \\
\hline Green Manure $\underline{\underline{b}}$ & $0.12 \mathrm{a} b$ & $19.0 \mathrm{c}$ & $0.25 b$ & $12.7 \mathrm{c}$ \\
\hline Cover crop $\underline{\underline{c}}$ & $0.15 a$ & $63.3 a b$ & $0.29 a$ & $55.7 \mathrm{ab}$ \\
\hline Zero-tillage & $0.15 a$ & $66.9 a$ & $0.29 a$ & $52.7 \mathrm{ab}$ \\
\hline NP-fertilizer & $0.15 a$ & $64.7 \mathrm{ab}$ & $0.29 a$ & $58.6 a$ \\
\hline
\end{tabular}

a Values are means of 4 replicates after two seasons of treatment application. Means followed by the same letter in a column are not significantly different by Tukey test $(P<0.05)$

b Velvet bean (Mucuna pruriens var. utilis)

$\therefore$ Arachis pintoi (accession CIAT 18744)

All technology options significantly reduced the weed biomass associated with maize. This reduction effect was considerably more in the long than in the short rainy seasons, irrespective of the soil type. The weed biomass was $30-80 \%$ higher in the short than long rainy season and tended to be less on Alfisols than on 
Ultisols at 12WAS (Table 5) with exception of farmers' practice on the Ultisols where $5-10 \%$ more weed biomass were observed in the long than in the short rainy seasons. Weed biomass was lowest in the cover crop treatment during the short rainy season at both sites.

Table 5: Effect of technology options on weed biomass in maize fields on the two dominant soil types in western Kenya (2008/09 cropping seasons).

\begin{tabular}{|c|c|c|c|c|c|c|c|c|c|}
\hline & Seasons & \multicolumn{4}{|c|}{ Short rainy season } & \multicolumn{4}{|c|}{ Long rainy season } \\
\hline & Soil types & \multicolumn{2}{|c|}{ Alfisol } & \multicolumn{2}{|c|}{ Ultisol } & \multicolumn{2}{|c|}{ Alfisol } & \multicolumn{2}{|c|}{ Ultisol } \\
\hline Options & WAPa & 8 & 12 & 8 & 12 & 8 & 12 & 8 & 12 \\
\hline \multicolumn{10}{|c|}{ Weed biomass $\underline{\text { b }}\left(\mathrm{kg} \mathrm{ha}^{-1}\right)$} \\
\hline \multicolumn{2}{|c|}{ Farmer practice (control) } & $574 a$ & $887 a$ & $816 a$ & $1222 a$ & $509 a$ & $668 a$ & $826 a$ & $1347 a$ \\
\hline \multicolumn{2}{|c|}{ Clean weeding } & $172 b$ & $439 b$ & $139 b$ & $545 b$ & $15 b$ & $20 \mathrm{~b}$ & $26 \mathrm{~b}$ & $34 b$ \\
\hline \multicolumn{2}{|c|}{ Seed Priming } & $171 b$ & $437 b$ & $137 b$ & $547 \mathrm{~b}$ & $15 \mathrm{~b}$ & $21 \mathrm{~b}$ & $28 \mathrm{~b}$ & $35 b$ \\
\hline \multirow{2}{*}{\multicolumn{2}{|c|}{ Animal Manure }} & $172 b$ & $440 b$ & $139 b$ & $548 b$ & $15 \mathrm{~b}$ & $22 \mathrm{~b}$ & $29 b$ & $37 \mathrm{~b}$ \\
\hline & & $150 b$ & $402 b$ & $135 b$ & $498 b$ & $13 b$ & $19 b$ & $15 b$ & $27 \mathrm{~b}$ \\
\hline \multicolumn{2}{|c|}{ Cover cropd } & $134 b$ & $233 c$ & $121 b$ & $378 c$ & $10 \mathrm{~b}$ & $13 b$ & $11 \mathrm{~b}$ & $11 \mathrm{~b}$ \\
\hline \multicolumn{2}{|c|}{ Zero-tillage } & $149 b$ & $431 b$ & $135 b$ & $597 b$ & $15 \mathrm{~b}$ & $20 \mathrm{~b}$ & $12 \mathrm{~b}$ & $17 \mathrm{~b}$ \\
\hline \multicolumn{2}{|c|}{ NP-Fertilizer } & $173 b$ & $439 b$ & $140 b$ & $549 b$ & $15 b$ & $23 b$ & $28 \mathrm{~b}$ & $38 \mathrm{~b}$ \\
\hline
\end{tabular}

a Weeks After Planting

$\underline{b}$ Values are means of 4 replicates. Means followed by the same letter in a column are not significantly different by Tukey $(P<0.05)$

c Velvet bean (Mucuna pruriens var. utilis)

¿ Arachis pintoi (accession CIAT 18744)

\section{Production factors requirement of technology options}

Technologies differed in their resource requirement. Labour and capital input requirements differed between technology options with highest labour input in green manure-based option and largest capital requirements for fertilizer-based options. Besides the technology options, labour requirements differed as a function of sites and season with a 5-10\% higher demand in the short rainy season than in the long rainy season irrespective of the soil types (Table 6). Green manure options required the highest labour input $(>100 \%)$ more than control followed by animal manure $(90-94 \%)$ and the mineral fertilizer-based treatments $(60-80 \%)$ while seed priming and clean weeding options required $54-70 \%$ more labour than the control treatment. In the long rainy season, the cover crop treatment required about $30 \%$ less labour than the control treatment. Observations on capital input (total variable costs excluding labour) permitted grouping of treatments as either low-input (clean weeding, seed priming, manure-based) or high-input (fertilizer-based) options. High-input technologies were associated with costs $>500 €$ ha $^{-1}$ while low-input options incurred costs $<100 €$ ha $^{-1}$. Seed priming and clean weeding were the cheapest options $\left(>30 € \mathrm{ha}^{-1}\right.$ ) and did not differ significantly from the control treatment (Table 6). 
Table 6: Nutrient inputs and production factors required for technology options to improve maize production and soil fertility in Western Kenya (2008/09 cropping seasons).

\begin{tabular}{|c|c|c|c|c|c|c|}
\hline \multirow[b]{2}{*}{ Options } & \multicolumn{2}{|c|}{ Nutrient inputs } & \multicolumn{4}{|c|}{ Production factors } \\
\hline & $\begin{array}{ll}\mathrm{N} & (\mathrm{kg} \\
\left.\mathrm{ha}^{-1}\right)\end{array}$ & $\begin{array}{l}P \\
\left(\mathrm{~kg} \mathrm{ha}^{-1}\right)\end{array}$ & $\begin{array}{l}\text { Labor } \\
\text { ha-1) }^{-1}\end{array}$ & (days & & \\
\hline & & & $\mathrm{SR}^{4}$ & LR $\underline{d}$ & $\mathrm{SR}$ & LRR \\
\hline Farmer practice (control) & - & - & $77 f$ & $70 \mathrm{e}$ & $24 \mathrm{e}$ & $24 \mathrm{e}$ \\
\hline Clean weeding & - & - & $120 e$ & $108 d$ & $24 \mathrm{e}$ & $24 \mathrm{e}$ \\
\hline Seed priming & - & - & $120 e$ & $108 d$ & $26 \mathrm{de}$ & 26de \\
\hline Animal manure & $60 \mathrm{~b}$ & $13 \mathrm{c}$ & $147 \mathrm{c}$ & $136 b$ & $60 \mathrm{c}$ & $60 \mathrm{~b}$ \\
\hline Green manure ${ }^{\mathrm{e}}$ & $45 c^{q}$ & $34 b$ & $166 a$ & $158 a$ & $44 \mathrm{~cd}$ & $44 \mathrm{~cd}$ \\
\hline Cover crop $₫$ & $100 a$ & $100 a$ & $153 b$ & $50 \mathrm{e}$ & $612 a$ & $536 a$ \\
\hline Zero-tillage & $100 a$ & $100 a$ & $121 e$ & $112 d$ & $536 b$ & $536 a$ \\
\hline NP-Fertilizer & $100 a$ & $100 a$ & $140 d$ & $129 b c$ & $536 b$ & $536 a$ \\
\hline
\end{tabular}

a Values are means of 4 replicates (sites), independent of soil types. Means followed by the same letter in a column are not significantly different by Tukey test $(\mathrm{P}<0.05)$.

$\underline{b}$ Labour includes; land preparation, seeding, manure/fertilizer application, green manure incorporation, weeding and harvesting

$\subseteq$ Capital includes costs of seeds (Maize, Mucuna pruriens and Arachis pintoi), animal manure and mineral fertilizer

$\underline{d}$ SR: short rainy season (August-November), LR: Long rainy season (February-July)

e Velvet bean (Mucuna pruriens var. utilis)

Arachis pintoi (accession CIAT 18744)

${ }_{9}^{9}$ Net $\mathrm{N}$ input by biological $\mathrm{N}_{2}$ fixation, based on \%Ndfa estimates using ${ }^{15} \mathrm{~N}$ natural abundance

Land and knowledge requirements were observed and ranked by farmers (results not presented). The ranking of land requirement was highest in the cover crop option permanently occupying the land as live mulch followed by the green manure option occupying the land 2 to 4 weeks prior to land preparation for maize. Knowledge requirements were considered highest in the seed priming followed by the zero-tillage and mineral fertilizer-based treatments.

\section{Economic evaluation of the technologies' performance}

A market survey conducted during the study period observed labour cost variations of 0.75 to $1.3 €$ day $^{-1}$ as a function of season and location with the lower values applied to the locations on Ultisol (remoteness from the market) and the short rainy season (lower competing labour demand). Maize price differed between harvesting time and the off-season from 0.26 $€ \mathrm{~kg}^{-1}$ (long rainy season) to $0.35 € \mathrm{~kg}^{-1}$ (short rainy season). The economic net benefits varied from -112 to $+892 €$ ha $^{-1}$. While largest net benefit occurred with manure-based options during the short rainy season, fertilizer-based options provided the highest net benefit during the long rainy season, irrespective of the soil type, with the exception of the cover crop which showed a negative net benefit on Alfisol (Table 7). Both MRR and dominance varied as a function of seasons. Based on their low net benefits, fertilizerbased options showed dominance only in the short rainy season (Table 7). The MRRs thus computed from the non-dominated treatments were $>100 \%$, regardless of seasons and soil types. 
Table 7: Economic analysis of technology options to improve maize yield and soil fertility on the two dominant soil types in Western Kenya (2008/09 cropping seasons).

\begin{tabular}{|c|c|c|c|c|c|c|c|c|}
\hline \multirow{3}{*}{ Options } & \multicolumn{4}{|c|}{ Alfisol } & \multicolumn{4}{|c|}{ Ultisol } \\
\hline & \multicolumn{2}{|c|}{ Net benefit $\left(€\right.$ ha $\left.^{-1}\right)$} & \multicolumn{2}{|c|}{$\operatorname{MRR}(\%)^{\mathrm{a}}$} & \multicolumn{2}{|c|}{ Net benefit $\left(€\right.$ ha $\left.^{-1}\right)$} & \multicolumn{2}{|c|}{$\operatorname{MRR}(\%)$} \\
\hline & SR $\underline{b}$ & LR & SR & LR & SR & $\mathrm{LR}$ & SR & LR \\
\hline Farmers practice (control) & 219 & 282 & - & - & 246 & 141 & - & - \\
\hline Clean weeding & 333 & 493 & 259 & 541 & 321 & 548 & 184 & 1042 \\
\hline Seed priming & 331 & 547 & 332 & 643 & 331 & 538 & 336 & 963 \\
\hline Animal manure & 360 & 652 & 132 & 363 & 350 & 631 & 110 & 480 \\
\hline Green manure $\underline{c}$ & 310 & 452 & 105 & 177 & 308 & 491 & 108 & 172 \\
\hline Cover crop $\underline{d}$ & -91 & -112 & 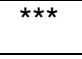 & $* \star \star *$ & -23 & 598 & $\star \star *$ & 108 \\
\hline Zero-tillage & 120 & 677 & 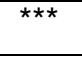 & 104 & 100 & 741 & $\star * *$ & 117 \\
\hline NP-fertilizer & 150 & 891 & 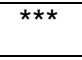 & 106 & 139 & 790 & $* * *$ & 124 \\
\hline
\end{tabular}

a MRR: Marginal Rate of Return; ${ }^{* * *}$ : Dominated by the farmers practice (control)

b SR: Short rainy; LR: Long rainy cropping seasons

c Velvet bean (Mucuna pruriens var. utilis)

d Arachis pintoi (accession CIAT 18744) 


\section{DISCUSSION}

\section{Agronomic performance of technology options}

In smallholder farming, the key performance parameters of technology options to improve soil fertility and/or weed suppression are yield increase (Odendo et al., 2009) and sustainable use of available resources (Woomer et al., 2003) or economic feasibility (CIMMYT, 1988). In this study, variations in maize grain yield on a seasonal basis were mainly influenced by the unreliable amount of rainfall experienced during the short rainy seasons as compared to the long rainy season which had a $20-70 \%$ higher rainfall and better distributed during the crop growth. Low and unreliable distribution of rainfall in western Kenya has been reported to cause $50-100 \%$ crop yield loss, especially in the short rainy season (Tittonell et al., 2008). Barron et al. (2003) reported maize yield loss of about $50 \%$ with less than $500 \mathrm{~mm}$ of total rain during the cropping season. Furthermore, leguminous crops have a high demand for soil water (Salako et al., 2003) and are likely to compete with an associated crop if seasonal rainfall is low (Rao and Mathuva, 2000). A reduction in yield of the main crop through competition by the cover crop has often been recognized as a serious problem in cover crop farming (Kleinhenz et al., 1997). Thus, the reduction in maize yield observed with the use of a cover crop could be partly ascribed to acute competition for soil moisture from the maize-associated cover crop. Similar observations were reported from drier areas of Kenya in an intercropping system of maize and Gliricidia (Rao and Mathuva, 2000), and in semi-arid areas of Tanzania in an intercropping system of maize and pigeon pea (Kimaro et al., 2009). Due to these side-effects the choice of a suitable cover crop species is crucial and depends on the environment of the cultivation and farmers' preferences (Campiglia et al., 2010). This could influence the applicability of these technology options particularly in this region especially during the unreliable short rainy season or on the sandy Alfisols with their low water-holding capacity. On the other hand, in a longerterm, such organic-based technology options may contribute to build organic matter and thus increasing soil water-holding capacity. This is true also for the application of farm yard manure (Ngome et al., 2011) or for zero-tillage (Giller et al., 2009). These options may be combined whereby a short-term build-up of soil organic $\mathrm{C}$ and the resulting water-holding capacity (i.e. by farm yard manure) may reduce the risks associated with cover crop (Campiglia et al., 2010). The lowest yield observed in the control treatment on the Ultisol particularly in the long rainy season, was probably due to high weed infestation on the clay-ultisols as reported earlier elsewhere (Chikoye et al., 2004). However, clean weeding alone was able to increase maize yields by $>66 \%$ at both sites. Though highest yields were observed with mineral fertilizer-based options, low-input manure-based options and seed priming combined with clean weeding significantly improved maize yields compared to the current farmers' practice and could be the starting point to increase production levels for cashconstrained subsistence farmers. The resulting yield increase may permit subsistence farmers to achieve food security (Ngetich et al., 2009) and to generate surpluses allowing for a shift to higher-input marketoriented and more sustainable production systems as reported earlier (Odendo et al., 2009).

Low soil nutrient contents (mainly $\mathrm{N}$ and $\mathrm{P}$ ) are widely recognized as the key constraint to increased crop production in western Kenya (Vanlauwe and Giller, 2006). Soil $N$ and $P$ improvement was thus assessed as one of the technology performance parameters. Differential response of soil $N$ and $P$ to soil type suggests the need to target the most limiting nutrient to a particular soil type. For instance, soil $\mathrm{N}$ is more deficient in Alfisol, while $\mathrm{P}$ is most deficient in Ultisol. Relatively little increases in soil $\mathrm{N}$ and $\mathrm{P}$ observed after two seasons of organic manure application indicate the need for a longer-term assessments as reported before from rice-based systems (Becker et al., 1994).

Weed infestation has been reported as one of the main production constraining factors facing smallholder farming in western Kenya (Vanlauwe et al., 2008). Any effort to improve crop yields by the introduction of new cropping and management options will be unrealistic if weed control is not part of the technology package. In this study, additional hand weeding reduced weed biomass by $>75 \%$, while increasing maize yield by $>60 \%$. Similar effects of improved weed control were recently reported by Vandeplas et al. (2010). However, the weed smothering effects of a cover crop were even more effective in the present study. As farmers in western Kenya commonly practice only one-weeding as a result of labour shortages (Odendo et al., 2006), weed control by cover crops appears a promising option in the low-input systems. Such approaches may gain further importance in the face of projected climate change (IPCC, 2008; Asch and Huelsebusch), whereby changing and increasing unreliable rainfall is likely to further enhance the weed problems.

\section{Technology requirement of production factors}

Smallholder farmers in western Kenya are faced with low labour availability (Tittonell et al., 2007) and poor access to capital (Salasys et al., 2007). In the present study, seasonal variations in weed infestation contributed to differences in labour use. The effective weeding done in the first (short rainy) season resulted in less weed infestation in the subsequent long rainy season and was thus able to free labour resource for other activities. Manure-based options

require extra labour for growing and incorporating the green biomass and applying the animal manure as reported earlier by Jama et al. (2000). While extra labour 
will be needed for seeding the cover crop (first season only) the smothering effect of the cover crop on weeds reduced labour use in the second season. These benefits are likely to be capitalized by the labourstrapped farms with either small family size or large land holdings. Any option that improves labour productivity is seen to generally improve acceptance by farmers in western Kenya (Ojiem et al., 2006; Tittonell et al., 2007).

The costs of variable inputs varied as a function of treatments. Organic manure-based options are a common practice in the region as animal manures and seeds of green manure crops are readily available (Ojiem et al., 2006). However, mineral fertilizers are often problematic because of their cost, the frequently untimely availability and the fact that no single $\mathrm{P}$ (or K)fertilizer is available in the markets of the region (Woomer et al., 2003). On the other hand, the extra land required for legume growth may worsen the already severe land shortages ( 0.5 ha per household), particularly in the subsistence farms where it is hardly affordable to set aside land for a crop that is not directly yielding food or income (Odendo et al., 2009). Sole soil improvement through the addition of biomass and biologically-fixed nitrogen may not be a sufficient incentive to farmers as has been observed in rice-and maize-based systems elsewhere (Becker et al., 1995; Carsky et al., 2001). However, A.pintoi can additionally be a source of animal fodder and can allow intercropping with other crops, provided moisture is not limiting (Jones and Bunch, 2003). Thus, A.pintoi could be a solution to the limited fodder availability in Kaka mega (Ngome and Mtei 2010) and combining soil fertility improvement, weed suppression and forage provision may be an alternative to farmers grazing large numbers of cattle (Boner et al., 2009). Seed priming requires extension services to guide farmers on the implementation of this option (Harris et al., 2001). However most farmers in the present study complained of poor and infrequent extension contacts (also reported by Salasya et al. (2007), which is likely to limit the adoption and the performance of priming-based technologies in western Kenya.

\section{Economic assessment}

Farm management principles normally use input-output analysis for the performance assessment of technology options (CIMMYT, 1988). The rationale of net benefit analysis was to compare returns from the different options while MRR and dominance analyses aimed at establishing percentage net returns when hierarchically comparing treatment options. Unlike the variability in the agronomic performance, the observed economic variability was mainly a function of output (yield) and the required labour and capital both differing between sites (soil, market distance) and with seasons. Changing from farmers practice to applying any of the non-dominated treatment options resulted on MRRs $>100 \%$, thus largely compensating for input cost while providing extra benefits. The MRRs also showed that the economically most viable options were not necessarily the ones providing the highest yields or net benefits, indicating that farmers' decision-making may not be restricted to profit maximization alone. Farmers also appear to consider the use-efficiency of available resources (Woomer et al., 2003; Salasya et al., 1998) and variability in the outcome as related to changes in the biophysical environment (rainfall variability) (Asch and Huelsebusch, 2009). The economic loss observed in the cover crop option on Alfisols was mainly due to the high cost of the mineral fertilizer used compared to the low yield obtained. However, this loss can be partially compensated for, by the added advantage of animal fodder provided by the $A$. pintoi (Jones and Bunch, 2003; Ngome and Mtei 2010) and act as a trade-off with the income from animal products. In this region, majority of the subsistence farmers have little knowledge about available alternative options and as a result they continue attempting to grow crops with minimal or no inputs and are thus trapped in the downward spiral of declining soil fertility, productivity and income (Giller et al., 2011; Salasya et al., 1998).

Agronomic assessment coupled with economic evaluations can help in defining production constraints and site-specific requirements thus providing the basis for targeting 'best-fit' specific technology options to specific site (socio-ecological niche) and defining extrapolation domains for technology adoption. Therefore, with improved extension efforts and market access coupled with site- specific targeting of technology options to address low soil fertility and high levels of weed infestation, crop productivity could be improved and ultimately the rural livelihood in western Kenya.

\section{ACKNOWLEDGEMENTS}

The authors acknowledge the financial support from the German Federal Ministry of Education and Research (BMBF) through the 'Biodiversity Monitoring Transect Analysis in Africa' (BIOTA) Project and the German Catholic Academic Exchange Services (KAAD) as well as institutional support from KARI Kakamega (Kenya), IRAD (Cameroon), University of Bonn (Germany) and University of Dar es salaam (Tanzania).

\section{REFERENCES}

Ajouri Z, Asgedom H, Becker M (2004). Seed priming enhances germination and seedling growth of barley under conditions of $\mathrm{P}$ and $\mathrm{Zn}$ deficiency. J. Plant Nutr. Soil Sc. 167: 630-636.

Asch F, Huelsebusch C, (2009). Agricultural research for development in the tropics: Caught between energy demands and food needs. J. Agr. Rural Dev. Trop. 110: 75-91.

Barron J, Rockstörm J, Gichuki F, Hatibu N (2003). Dry spell analysis, and maize yields for two semi-arid locations in East Africa, Agr. Forest Meteorol. 117: 23-37. 
Becker M, Ladha JK, Ottow JCG,(1994). Nitrogen losses and lowland rice yield as affected by residue $\mathrm{N}$ release. Soil Sci. Soc. Am. J. 58: 1660-1665.

Becker M, Ali M, Ladha JK, Ottow JCG (1995). Agronomic and economic evaluation of Sesbania rostrata green manure establishment in irrigated rice. Field Crop. Res. 40: 135141.

Böner J, Mburu J, Guthiga P, Wambua S (2009). Assessing opportunity costs of conservation: Ingredients for protected area management in Kaka mega Forest, Western Kenya. Forest Policy Econ. 11: 459-467.

Campiglia E, Mancinelli R, Radicetti E, Caporali F (2010). Effects of cover crops and mulches on weed control and nitrogen fertilization in tomato (Lycopersicon esculentum Mill.). Crop Prot. 29: 354-363.

Carsky RJ, Becker M, Hauser S (2001). Mucuna cover crop fallow systems: Potential and limitations, in: G. Tian, F. Ishida, D. Keatinge (Eds.), Sustaining Soil Fertility in West Africa, SSSA Special Publication, SSSA and ASA, Madison, WI, USA, , pp.111-135.

Chikoye D, Schulz S, Ekeleme F (2004). Evaluation of integrated weed management practices for maize in the northern Guinea Savanna of Nigeria, Crop Prot. 23: 895900.

CIMMYT (1988). From agronomic data to farmer recommendations: an economics training manual (completely revised edition). International Maize and Wheat Improvement Centre (CIMMYT), Mexico.

Diwani T, Becker M (2009). Farming system and soil fertility management in Kakamega, Western Kenya, in: K. Gaesing (ed.), Reconciling Rural Livelihood and Biodiversity Conservation Spring Research Series No.52 Dortmund, Germany, pp.75-93.

Doss CR (2006). Analyzing technology adoption using micro studies: limitations, challenges and opportunities for improvement, Agr. Econ. 34: 207-219.

$\mathrm{FAO}$, Soil fertility management in support of food security in sub-Saharan Africa. Food and Agricultural Organization of the United Nations, Rome, Italy, 2001.

FURP, Fertilizer Use Recommendations Vol. 1-23 KARI Nairobi, Kenya, 1994.

Giller, KE, Tittonell P, Rufino MC, et al., (2011). Communicating complexity: Integrated assessment of trade-offs concerning soil fertility management within African farming systems to support innovation and development. Agr. Syst. 104: 191-203.

Giller KE, Rowe E, de Ridder EN, van Keulen H (2006). Resource use dynamics and interactions in the tropics: scaling up in space and time, Agr. Syst. 88: 8-27.

Giller KE, Witter E, Corbeels M, Tittonell P (2009). Conservation agriculture and smallholder farming in Africa: the heretics' view, Field Crop Res. 114: 23-34.

Harris D, Pathan AK, Gothkar P, Joshi A, Chivasa W, Nyamudeza P (2001). On farm seed priming: using participatory methods to revive and refine a key technology. Agr. Syst. 69: 151-164.

IPCC (2008). Climate change and water, in: B.C Bates, Z.W. Kundzewic, J.P. Palutikof (Eds.) Technical Paper VI. Intergovernmental Panel on Climate Change Secretariat, Geneva, Switzerland, pp.210.

Jaetzold R, Schmidt H, Hornetz B, Shisanya C (2005). Farm management handbook of Kenya Vol II, Natural Conditions and Farm Management Information, second ed. Part A: West Kenya, Subpart A1: Western Province. Ministry of Agriculture, Kenya in Cooperation with the German Agency for Technical Cooperation (GTZ), Nairobi, Kenya.
Jama B, Palm CA, Buresh RJ, Niang A, Gachengo C Nziguheba G, Amadalo B (2000). Tithonia diversifolia as a green manure for soil fertility improvement in western Kenya: A review. Agr. Syst. 49: 201-22.

Jones RM, Bunch GA (2003). Experiences with farm pastures at the former CSIRO Samford Research Station, southeast Queensland, and how these relate to results from 40 years of research. Trop. Grasslands 37: 151-164.

Kimaro AA, Timmer VR, Chamshama SAO, Ngaga YN, Kimaro DA (2009). Competition between maize and pigeonpea in semi-arid Tanzania: Effects on yields and nutrition of crops. Agr. Ecosyst. Environ. 134: 115-125.

Kleinhenz V, Schnitzler WH, Midmore DJ (1997). Effects of legume live-mulch on crop performance, soil available nitrogen and crop $\mathrm{N}$ status in intensive tropical vegetable production. Biol. Agric. Hortic. 14: 261-278.

Ngetich KA, Birech RJ, Kyalo D, Bett KE, Freyer B (2009). Caught between energy demands and food needs: dilemmas of smallholder farmers in Njoro, Kenya J. Agr. Rural Dev. Trop. 110 (1): 23-28.

Ngome AF, Becker M, Mtei KM, Mussgnug F (2011). Fertility management for maize cultivation in some soils of Western Kenya. Soil Till. Res. 117: 69-75.

Ngome FN, Mtei KM (2010). Establishment, biological nitrogen fixation and nutritive value of Arachis pintoi (CIAT 18744) in western Kenya. Trop. Grasslands 44: 289-294.

Odendo M, Ojiem J, Bationo A, Mudeheri M (2006). On-farm evaluation and scaling-up of soil fertility management technologies in western Kenya. Nutr. Cycl. Agroecosys. 76: 369-381.

Odendo M, Obare G, Salasya B (2009). Factors responsible for differences in uptake of integrated soil fertility mamagement practices amongst smallholders in western Kenya. Afr. J. Agric. Res. 4: 1303-1311.

Odendo M, Ojiem J, Okwuosa E (2004). Potential for adoption of legume green manure on smallholder farms in western Kenya, in: A. Bationo (Ed.), Managing Nutrient Cycles to Sustain Soil Fertility in sub-Saharan Africa, Academy Science Publishers Nairobi, Kenya, pp.557-570.

Ojiem JO, de Ridder, N, Vanlauwe B, Giller KE (2006). Socioecological niche: a conceptual framework for integration of legumes in smallholder farming systems. Int. J. Agric. Sustain. 4: 79-93.

Okalebo JR, Othieno CO, Woomer PL, Karanja NK, Semoka JRM, Bekunda MA, Mugendi DN, Muasya RM, Bationo A, Mukhwana EJ (2006). Available technologies to replenish soil fertility in East Africa, Nutr. Cycl. Agroecosys. 76: 153170.

Okalebo JR, Gathua KW, Woomer PL (2002). Laboratory methods of soil and plant analysis: A working manual. $2^{\text {nd }}$ Ed. TSBF-CIAT and SACRED Africa, Nairobi, Kenya.

Rao MR, Mathuva MN (2000). Legumes for improving maize yields and income in semi-arid Kenya. Agr. Ecosyst. Environ. 78: 123-137.

Salako FK, Tian G (2003). Soil water depletion under various leguminous cover crops in the derived savannah of West Africa, Agr. Ecosyst. Environ. 100: 173-180.

Salasya BD, Mwangi W, Mwabu D, Diallo A (2007). Factors influencing adoption of stress-tolerant maize hybrid (WH $502)$ in western Kenya. Afr. J. Agric. Res. 2: 544-551.

Salasya BD, Mwangi W, Verjurl H, Odendo MA, Odenya JA (1998). An assessment of the adoption of seed and fertilizer packages and the role of credit in smallholder maize production in Kakamega and Vihiga districts, CIMMYT Publication, Mexico, pp.50.

Shepherd KD, Soule MJ (1998). Soil fertility management in west Kenya: Dynamic simulation of productivity, 
profitability and sustainability at different endowment levels, Agr. Ecosyst. Environ. 71: 131-145.

SPSS (2008). Statistical Package for Social Sciences version 17.0 for windows. SPSS Inc., Chicago, USA.

Tittonell P, Vanlauwe B, Leffelaar PA, Rowe EC, Giller KE (2005a). Exploring diversity in soil fertility management of smallholder farms in western Kenya I. Heterogeneity at region and farm scale. Agr. Ecosyst. Environ. 110: 149165.

Tittonell P, Vanlauwe B, Leffelaar PA, Shepherd KD, Giller KE (2005b). Exploring diversity in soil fertility management of smallholder farms in western Kenya II Within-farm variability in resource allocation, nutrient flows and soil fertility, Agr. Ecosyst. Environ. 110: 166-184.

Tittonell P, Muriuki A, Shepherd KD, Mugendi D, Kaizzi KC, Okeyo J, Verchot L, Coe R, Vanlauwe B (2010). The diversity of rural livelihoods and their influence on soil fertility in agricultural systems of East Africa - A typology of smallholder farms. Agr. Syst. 103: 83-97.

Tittonell P, Shepherd KD, Vanlauwe B, Giller KE (2008). Unravelling the effects of soil and crop management on maize productivity in smallholder agricultural systems of western Kenya - An application of classification and regression tree analysis, Agr. Ecosyst. Environ. 123: 137150.
Tittonell P, van Wijk MT, Vrugt JA, Giller KE (2007). Analysing trade-offs in resource and labor allocation by smallholder farmers using modelling techniques: A case-study from Kakamega district. Western Kenya. Agr. Syst. 95: 75-95.

Vandeplas I, Vanlauwe B, Driessens L, Merckx R, Deckers J (2010). Reducing labour and input costs in soybean production by smallholder farmers in south-western Kenya. Field Crop Res. 117: 70-80.

Vanlauwe B, Giller KE (2006). Popular myths around soil fertility management in sub-Saharan Africa: Nutrient management in tropical agroecosystems. Agr. Ecosyst. Environ. 116: 34-46.

Vanlauwe B, Kanampiu F, Odhiambo GD, de Groote H, Wadhams LJ, Khan ZR (2008). Integrated management of Striga hermonthica, stemborers, and declining soil fertility in western Kenya. Field Crop Res. 107: 102-115.

Waithaka MM, Thornton PK, Herero M, Shepherd KD (2006). Bio-economic evaluation of farmers' perception on viable farms in western Kenya. Agr. Syst. 90: 243-271.

Wall E, Smit B (2005). Climate change adaptation in light of sustainable agriculture. J. Sustain. Agric. 27 (1): 113-123.

Woomer PL, Okalebo JR, Maritim H, Obura PA, Mwaura FM, Nekesa P, Mukhwana EJ (2003). PRE-PAC: a nutrient replenishment product designed for smallholders in western Kenya. Agr. Ecosyst. Environ. 100: 295-303.

Cite this Article: Mtei KM, Ngome AF, Wambua S and Becker M (2013). Assessment of Technology Options Addressing Agricultural Production Constraints in Western Kenya. Greener Journal of Agricultural Sciences, 3(3): 222-234, http://doi.org/10.15580/GJAS.2013.3.102412135. 